\title{
The Analysis on the Influence Factors and Tendency of Power Regulation in China
}

\author{
Q. Guo, T. Liu, G.W. Gao, Y. Xu \\ State Grid Energy Research Institute \\ China
}

\begin{abstract}
Regulation is very useful in remedy the market failure effect caused by monopoly, especially in natural monopoly industry such as electricity. This paper first reviews the regulation situation in China's power industry, and then we analyze the influence factors that have influence on the regulation in power industry. At last we suggest a development path for China's power regulation.
\end{abstract}

Keywords-power regulation; influence factors; China power industry

\section{Regulation Situation In ChinA's POWER INDUSTRY}

Regulation refers to the restrictions that the government implements to the enterprises within an industry, including market access, pricing and service quality, health, safety and environmental regulations. Electricity Grid as a typical natural monopoly industry is needed to design effective mechanism government regulation to make up market failure caused by monopoly.

\section{A. Regulatory Pattern}

In 2002, after the electricity reform, the former state power company was separated into five power generation group and two power grid companies. The industry structure was transformed from the traditional vertical integration to the competition in power generation and government regulation in power transmission and distribution. Meanwhile, since the feed-in tariff was still approved by the national development and reform commission, the real competitive feed-in tariff has not been formed. In power grid, due to natural monopoly characteristics of grid, distribution electricity price was strictly regulated by the government. The transmission price is computed by the difference between the buying prices and selling, actually it is the cost-plus pricing method.

\section{B. Regulatory System}

In March 2003, the state electricity regulatory commission (hereinafter referred to as SERC) was established was to fulfill the national electricity regulatory responsibilities. The SERC gradually established a power regulatory organization system in national, regional and provincial level. In February 2005, the electricity regulatory ordinance was carried out, which became the SERC's regulation basis in legal. Electricity regulator subsequently carried out a series of regulation rules, which covered power safety and quality of power supply, market construction and supervision work. In March
2008, the national energy administration was established, which was responsible for the formulation and organize the implementation of the energy industry planning, industrial policy and standards, the development of new energy, promote energy conservation, etc. In March 2013, the SERC was canceled, and was combined with the national energy administration.

So far, China has established the basic framework of power regulation, with the gradual reform of electricity market, power regulation will dynamically change to meet the requirements of market-oriented reform.

\section{The MAIN FACtORS InfUlEnCING THE CHINESE POWER REGULATION}

With the new government came to effect, and gradually shifted the way of economic development, the government paid more attention to the quality of economic development. The year 2014 was regarded as the new "first year of reform", the political system and economic system reform has entered a new historical period. Power industry as the pillar industry of national economy, the development of this industry became mature, and the industry structure became more reasonable day by day. The main factors influencing the power regulation include economic development environment, government reform, electric power industry development, and electricity market reform.

\section{The Economic Development Environment}

The new government gradually abandoned the GDP standard development pattern, and government gradually controlled the development of energy-intensive industries. With economic growth gradually slowed down, economic development will face the more tightly environmental constraint. China's urbanization will get into the fast track, the development of urbanization rate will increase at a rate of $1 \%$ per year, and the rapid growth of urbanization will further enhance the requirement of power supply quality and safety. However, the growth rate of GDP in China would still in a mid-high track, the network regulation should be to achieve the sustainable development of national economy as the ultimate goal, to ensure the power industry's long-term capacity adequacy, and get enough allowed revenues for power grid companies to ensure that the power grid enterprises have the ability to pay the necessary operation cost and investment cost, and have the incentives to conduct electricity infrastruc- 
ture construction as well as the transmission network investment enthusiasm in the long term.

\section{The Government Reform}

The transformation of government function, reduce the decentralization is the core of government reform. In 2013 the government institutional reform combined SERC with the national energy bureau. At the same time, the state council canceled administrative approval several times.

After decentralization, the regulation on power grid would have some changes in the content and key point. One is that in the market regulation, the decentralization has greatly simplified the advance program, and focuses more on strengthening the regulation afterwards. The second change is regulation content. Before and decentralization, power regulation mainly depends on investment approval, market access regulation, which is not good to stimulate the market and the vitality of enterprises. After the decentralization, regulation focuses more on the fair access, order of the electricity market and the power quality.

\section{E. The Development of the Power Industry}

With the economic development slow down, the overall demand of Chinese power industry will grow steady, and the structure of the generation become cleaner. The exploitation of power generation mainly concentrated and scattered supplemented. The ability of wide range resource allocation on power will markedly be enhanced. The power consumption will be more on green resource and be more efficient and intelligent interactive.

One is the development of new energy will have a great influence on power grid interconnection access, and the higher request for the power grid dispatching. Second, with the development of the UHV technology, the power regulation in the future will focus more on the safe and stable operation of power grid. Third, with the development of smart grid, power system security and stability is the primary task of electricity network regulation.

\section{F. The Power Market-Oriented Reform}

Along with the advancement of electric power market reform, power regulation will guide the power grid enterprises to increase renewable energy transmission, key technology such as optimization of electric power dispatching and operation control in the field of research and development, and guide enterprises to carry out more long-term planning, investment and construction, strengthen the whole assets life cycle management. All these will provide the necessary economic incentives the power grid enterprises to reduce costs and improve efficiency, and provide a solid foundation to the direct trading between the large industry users and generation firms.

\section{The ANALysis ON THE REgUlatory DeVElopMENT PATH OF CHINA's POWER INDUSTRY}

According the regulatory status and influencing factors of China's electricity industry, we put forward the regulation development path of China's electricity industry, including the near future, medium-term and long-term three stages.

In the near future, the government should focus on the improvement of the function, change the focus of management. Enhance comprehensive energy management departments coordination function, make the regulation function of regulator be more perfect, and strengthen the construction of the supervisory ability of the regulator. Management focus should turn from the energy production and supply to focus more on demand, from economic regulation to social regulation.

In the medium-term, the government should focus on the reform of government institutions, straighten out the relationship between the different regulatory bodies, and straighten out the relationship between the central regulation and local regulation. In order to enhance the government's administrative execution ability as the main line, the energy management institutions should be reformed. From the organization guarantee, system guarantees two respects, to realize the goal of the central and local consistency.

In the long run, the regulation should be formed in accordance with the law, effectively promote the sustainable development of the new management system and a long-term mechanism. Forming perfect energy management and supervision system of laws and regulations, and focus on energy saving and improving energy efficiency, ensuring the safety and renewable energy development and so on.

\section{REFERENCES}

[1] Estache. A, Rossi. M. A. Do Regulation and Ownership Drive the Efficiency of Electricity Distribution, Evidence from Latin America, Economics Letters, 86(2), 253-257, 2005.

[2] Richard A. Posner, “Theory of Economic Regulation,” Bell Journal of Economics and Management Science, pp.335-338, 1974

[3] Sappington, D.E.M. and Sibley, D.S. "Regulating without Cost Information: The Incremental Surplus Subsidy Scheme”, International Economic Review, pp.297-306, 1988.

[4] Sappington, D.E.M. and Sibley, D.S. "Strategic Nonlinear Pricing under Price-Cap Regulation”, Rand Journal of Economics, pp.1-19, 1992.

[5] Coen, D. and Thatcher, M., "Network governance and multilevel delegation: European networks of regulatory agencies”, Journal of Public Policy, 49-71, 2008.

[6] Finger, M. and Varone, F., "Bringing technical systems back in: towards a new European model of regulating the network industries", Competition and Regulation in Network Industries, 87-106, 2006. 